\title{
The Store Ambience in Beauty Salon Business in Surabaya, Indonesia
}

\author{
Steven Evaldo Sunefo and Dhyah Harjanti* \\ Department of Management, Faculty of Business and Economics, Petra Christian University, \\ Jl. Siwalankerto 121-131, Surabaya 60236, Indonesia
}

\begin{abstract}
In big cities, the existence of a beauty salon is very expected among the life of their citizens. The social media, such as Instagram, also trigger the citizen to care for their physical appearances for their selfie pictures for posting their groups. As a beauty salon is offering services, the tangible aspects become crucial in attracting the customers. The aim of this research is to examine the influence of store atmosphere on satisfaction and loyalty among the beauty salon customers. This research belongs to the causal research, in which the data are collected from the sampling of a population, with the accidental sampling technique. The numbers of the sample are 200 respondents. The data, then, are processed with the assistance of a software application of SmartPLS. The results of the research are obtained as the store atmosphere has a positive significant influence on the customer satisfaction, the store atmosphere also has a positive significant influence on customer loyalty, and the customer satisfaction has appositive significant influences on customer loyalty.
\end{abstract}

Keywords: Customer satisfaction, customer loyalty, store atmosphere.

\section{Introduction}

Rapid business development requires every entrepreneur to be able to determine the right strategy in seizing the existing market share. Companies can focus on the consumer shopping experience as a material consideration for designing a marketing strategy policy. One form of strategy that can be implemented is to consider the store atmosphere.

The store atmosphere is an atmosphere referring to the physical characteristics of the store that project images and attract customers [1]. Sezgin and Küçükköylü, explained that the store atmosphere including those related to the physical elements of a store and everything related to the internal parts of the store including shop equipment, shop facilities, and external stores including the store environment and others [2]. There are two main groups of store atmosphere related to external and internal, where the exterior describes the outside of the store that can attract people to visit the store, while in terms of internal describe the interior of the store that illustrates the maximum arrangement of goods available in stores. The purpose of the store atmosphere is to create a condition that gives a different flavor to store customers so that it is easy to remember the uniqueness of a store and create sentimental feelings in increasing user satisfaction so that more frequent

*Corresponding author: dhyah@petra.ac.id 
shopping transactions. A positive or pleasant atmosphere will cause shoppers to spend more time in the store.

Wang and Ha's research found that store atmosphere has an effect on increasing consumer satisfaction [3]. Customer satisfaction is a situation that is shown by customers when they realize that their needs and desires are as expected and are met properly. Kotler and Keller, said that customer satisfaction is something that is expressed or not expressed to a feeling of happiness or disappointment about something received for service performance and that has been promised, if the service performance is better than promised, happiness will occur and vice versa [4]. If product delivery to customer is less than expectations, customers will be disappointed and if product performance is commensurate with expectations, customers will be satisfied and if product delivery pass through the expectations, then the customer is very happy [4].

Carranza and Diaz's research proves when consumer satisfaction will be increase effect on customer loyalty [5]. Kotler and Keller define customer loyalty as the long-term success of a particular brand based on the number of customers who don't only buy once but on the amount that is a repeat purchase [4]. Garcia and Caro also explained that loyal customers are customers who make continuous purchases, not only buying one product but buying other products at the same business entity and recommending it to others and not being tempted by competitors [6]. This study aims determine effect of store atmosphere in beauty salon to customer satisfaction, and impact store atmosphere to loyalty in beauty salon services in Surabaya, Indonesia.

The atmosphere of the store is one of the things that customers consider when going shopping. A pleasant atmosphere will affect the level of customer satisfaction [7]. Customer satisfaction is a situation that is shown by customers when they realize that their needs and desires are as expected and well fulfilled [4]. The results of Miswanto and Angelia's research, prove that the store atmosphere has a positive influence on customer satisfaction [7]. The results of Dabija and Babut's research, found a significant and positive influence between store atmosphere and satisfaction [8].

$\mathrm{H}_{1}$ : Store atmosphere affects consumer satisfaction significantly in beauty salon services.

The store atmosphere including those related to the physical elements of a store and everything related to the internal parts of the store including shop equipment, shop facilities, and external stores including shop environment and others [1]. The purpose of the store atmosphere is to create a condition that gives a different flavor to store customers so that it is easy to remember the uniqueness of a store and create sentimental feelings in increasing user satisfaction so that more frequent shopping transactions [2].

The atmosphere of the shop can be a reason for customers to be interested and choose where he will visit and buy [9]. The tendency to visit and buy back a certain product or service leads to customer loyalty. Loyalty is the customer's commitment to make repeated purchases of products and say positive things about them, and customers also receive services and products produced in the future [4]. Furoida and Maftukhah research results, prove that the store atmosphere has effect on customer loyalty [9].

$\mathrm{H}_{2}$ : $\quad$ Store atmosphere affects consumer loyalty significantly in beauty salon services.

Having loyal customers is the goal of the company because customers can ensure longterm sustainability. Loyalty when consumers are satisfied and motivated to continue the relationship with the Furoida and Maftukhah brands [9]. Kotler and Keller, states that satisfaction is said that customer satisfaction is something that is expressed or not expressed to a feeling of happiness or disappointment about something received on the performance of services and that has been promised [4]. 
Customer loyalty can be interpreted as a commitment or principle held by customers to buy and support that are preferred in the future and there are marketing efforts that can make customers change their minds [4]. Furoida and Maftukhah research results, prove that customer satisfaction affects customer loyalty [9]. Carranza and Diaz's research results also consumer satisfaction has a significant to increase the customer loyalty [5].

$\mathrm{H}_{3}$ : Consumer loyalty affects consumer loyalty in beauty salon services.

$\mathrm{H}_{4}$ : Consumer satisfaction mediates the effect of store atmosphere to consumer loyalty in beauty salon services.

\subsection{Research framework}

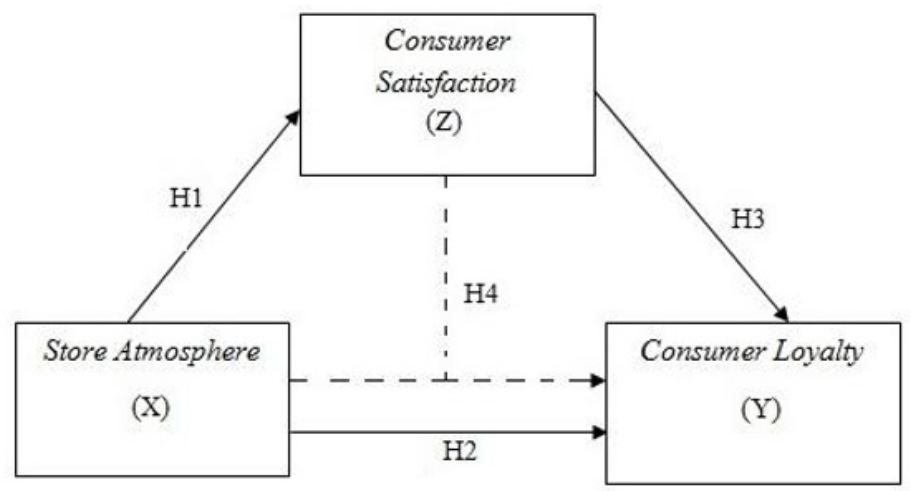

Fig. 1. Research framework

\section{Research framework}

This research uses quantitative data analysis and uses questionnaire data collection methods. This study is included in the type of causal research because one variable with other variables is interrelated namely the independent variable and the dependent variable.

The population in this study is the beauty salon consumers. The determination of the sample is done use judgmental sampling, which is a sampling technique with certain considerations. The consideration of sampling using the following criteria:

i). Minimum 16 yr old

ii). Been to a beauty salon in the past 6 mo

In this study a technique of determination of the sample based on the approval submitted by the researcher regarding the store asking the researcher to place in the shop at certain hours where there are many store customers. Every shop visitor who is dating gives a questionnaire to fill in and conducts initial clarification through interviews that have increased $16 \mathrm{yr}$. In this study, two types of variables are exogenous (independent) and endogenous (dependent) variables. Endogenous variables in this study are Consumer Satisfaction (Z) and Consumer Loyalty (Y). The exogenous variable in this study is Store Atmosphere (X). The analysis technique in this research is Partial Least Square (PLS) analysis, using Smart Partial Least Square (PLS) software.

\section{Analysis and discussion}

\subsection{Convergent validity}


To test convergent validity, when indicator said to be in the good category if it has a loading factor $>0.50$. However, for the initial research stage of developing the measurement scale, the value of loading factors 0.5 to 0.6 is still considered sufficient [10]. The results of the correlation between the indicator with the contract as shown Table 1 .

Table 1. Convergent validity

\begin{tabular}{|c|c|c|c|c|c|}
\hline & $\begin{array}{c}\text { Original } \\
\text { Sample }(0)\end{array}$ & $\begin{array}{c}\text { Sample } \\
\text { Mean (M) }\end{array}$ & $\begin{array}{l}\text { Standard } \\
\text { Deviation } \\
\text { (STDEV) }\end{array}$ & $\begin{array}{l}\text { T- Statistics } \\
\text { (|O/STDEV|) }\end{array}$ & P Values \\
\hline \multicolumn{6}{|c|}{ Store Atmosphere (X) } \\
\hline $\mathrm{X} 1$ & 0.539 & 0.535 & 0.069 & 7.853 & 0.000 \\
\hline $\mathrm{X} 2$ & 0.600 & 0.596 & 0.057 & 10.515 & 0.000 \\
\hline X3 & 0.667 & 0.664 & 0.050 & 13.325 & 0.000 \\
\hline $\mathrm{X} 4$ & 0.706 & 0.703 & 0.043 & 16.492 & 0.000 \\
\hline X5 & 0.691 & 0.687 & 0.049 & 13.955 & 0.000 \\
\hline X6 & 0.724 & 0.720 & 0.040 & 18.260 & 0.000 \\
\hline $\mathrm{X} 7$ & 0.665 & 0.659 & 0.056 & 11.900 & 0.000 \\
\hline $\mathrm{X} 8$ & 0.715 & 0.710 & 0.045 & 15.765 & 0.000 \\
\hline X9 & 0.754 & 0.751 & 0.036 & 20.711 & 0.000 \\
\hline $\mathrm{X} 10$ & 0.681 & 0.680 & 0.040 & 17.023 & 0.000 \\
\hline $\mathrm{X} 11$ & 0.742 & 0.742 & 0.031 & 24.220 & 0.000 \\
\hline $\mathrm{X} 12$ & 0.631 & 0.624 & 0.063 & 10.050 & 0.000 \\
\hline X13 & 0.567 & 0.563 & 0.064 & 8.815 & 0.000 \\
\hline \multicolumn{6}{|c|}{ Consumer Satisfaction $(\mathrm{Z})$} \\
\hline $\mathrm{Z1}$ & 0.921 & 0.921 & 0.013 & 73.596 & 0.000 \\
\hline $\mathrm{Z} 2$ & 0.930 & 0.930 & 0.011 & 88.056 & 0.000 \\
\hline $\mathrm{Z} 3$ & 0.877 & 0.877 & 0.017 & 50.790 & 0.000 \\
\hline \multicolumn{6}{|c|}{ Consumer Loyalty (Y) } \\
\hline $\mathrm{Y} 1$ & 0.845 & 0.845 & 0.019 & 43.561 & 0.000 \\
\hline $\mathrm{Y} 2$ & 0.870 & 0.870 & 0.024 & 36.063 & 0.000 \\
\hline Y3 & 0.865 & 0.864 & 0.018 & 47.421 & 0.000 \\
\hline Y4 & 0.711 & 0.709 & 0.043 & 16.377 & 0.000 \\
\hline
\end{tabular}

Based on Table 1 Store Atmosphere Variables (X) measured by 13 measurement items, all are declared valid because value is $>0.5$. Likewise, the Consumer Satisfaction variable (Z) as measured by three items statement of all the indicators declared valid because the loading factor value $>0.5$. The construct variable Consumer Loyalty (Y) with four indicators which are all declared valid.

\subsection{Discriminant validity}

The discriminant validity test aims to test the validity of the indicator block. The discriminant validity test uses cross-loading values. Based on Table 2 above, it can be concluded that all constructs in the estimated model meet the discriminant validity criteria, because they have the largest cross-loading value on the variable they form compared to the cross-loading value on other variables. 
Table 2. Cross loading

\begin{tabular}{lccc}
\hline & $\begin{array}{c}\text { Store } \\
\text { Atmosphere (X) }\end{array}$ & $\begin{array}{c}\text { Consumer } \\
\text { Satisfaction }(\mathbf{Z})\end{array}$ & $\begin{array}{c}\text { Consumer } \\
\text { Loyalty (Y) }\end{array}$ \\
\hline X.1 & 0.539 & 0.365 & 0.339 \\
X.2 & 0.600 & 0.398 & 0.340 \\
X.3 & 0.667 & 0.490 & 0.460 \\
X.4 & 0.706 & 0.429 & 0.438 \\
X.5 & 0.691 & 0.512 & 0.425 \\
X.6 & 0.724 & 0.599 & 0.530 \\
X.7 & 0.665 & 0.534 & 0.493 \\
X.8 & 0.715 & 0.519 & 0.434 \\
X.9 & 0.754 & 0.546 & 0.505 \\
X.10 & 0.681 & 0.538 & 0.507 \\
X.11 & 0.742 & 0.599 & 0.592 \\
X.12 & 0.631 & 0.439 & 0.451 \\
X.13 & 0.567 & 0.466 & 0.480 \\
Z.1 & 0.702 & 0.921 & 0.681 \\
Z.2 & 0.687 & 0.930 & 0.686 \\
Z.3 & 0.650 & 0.877 & 0.675 \\
Y.1 & 0.632 & 0.713 & 0.845 \\
Y.2 & 0.590 & 0.639 & 0.870 \\
Y.3 & 0.633 & 0.603 & 0.865 \\
Y.4 & 0.416 & 0.491 & 0.711 \\
\hline
\end{tabular}

\subsection{Average Variance Extracted (AVE)}

AVE illustrates the discriminant extracted on each indicator so that the ability of each item to share measurements with others can be known. The AVE value $>0.50$ indicates a good category.

Table 3. Average Variance Extracted (AVE)

\begin{tabular}{lc}
\hline & Average Variance Extracted (AVE) \\
\hline Store Atmosphere $(\mathrm{X})$ & 0.550 \\
Consumer Satisfaction $(\mathrm{Z})$ & 0.827 \\
Consumer Loyalty $(\mathrm{Y})$ & 0.682 \\
\hline
\end{tabular}

In Table 3, the AVE value for Store Atmosphere (X) is 0.550 , Consumer Satisfaction $(\mathrm{Z})$ is 0.827 and consumer loyalty $(\mathrm{Y})$ is 0.682 . At the critical limit of 0.5 , the indicators in each construct have good discriminant validity.

\subsection{Composite reliability}

Composite reliability is a part that is used to test the reliability value of indicators on a variable. A variable can be stated, fulfilling composite reliability if it has a composite reliability value $>0.70$. Here are the composite reliability values of each variable used in this study: 
Table 4. Composite reliability

\begin{tabular}{lc}
\hline & Composite Reliability \\
Store Atmosphere (X) & 0.913 \\
Consumer Satisfaction (Z) & 0.935 \\
Consumer Loyalty (Y) & 0.895 \\
\hline
\end{tabular}

Based on Table 4 it can be explained that from the provisions of good composite reliability is 0.7 it can be stated that each variable has met the composite reliability so that it can be concluded that all variables are adequate in measuring latent or construct variables that are measured so that it can be used in further analysis.

\subsection{Cronbach's alpha}

The reliability test with composite reliability above can be strengthened by using Cronbach alpha value. A variable can be declared reliable or satisfies Cronbach's alpha if it has a Cronbach's alpha value $>0.6$.

Table 5. Cronbach's alpha

\begin{tabular}{lc}
\hline & Cronbach's Alpha \\
\hline Store Atmosphere (X) & 0.897 \\
Consumer Satisfaction (Z) & 0.895 \\
Consumer Loyalty (Y) & 0.843 \\
\hline
\end{tabular}

Based on the test results in the above table, it can be seen that the Cronbach's alpha value of each study variable is $>0.60$. Thus these results can indicate have a high level of reliability test.

\subsection{Inner model evaluation}

In assessing a model with PLS, it starts by looking at the R-square for each latent dependent variable. Changes in the value of $\mathrm{R}$-square can be used to assess the effect of certain independent latent variables on the dependent latent variable whether it has a substantive effect. For endogenous latent variables in the structural model which has an $\mathrm{R}^{2}$ of 0.75 indicating that the model is "strong," $\mathrm{R}^{2}$ of 0.50 indicates that the model is "moderate," $\mathrm{R}^{2}$ of 0.25 indicates that the model is "weak" [10]. The PLS output as described below:

Table 6. The R-square model value

\begin{tabular}{lc}
\hline & R Square \\
\hline Store Atmosphere $(\mathrm{X})$ & - \\
Consumer Satisfaction $(\mathrm{Z})$ & 0.559 \\
Consumer Loyalty $(\mathrm{Y})$ & 0.603 \\
\hline
\end{tabular}

The latent variable Store Atmosphere (X), which influences the Consumer Satisfaction variable $(Z)$ in the structural model, has an $\mathrm{R}^{2}$ value of 0.559 which indicates that the model is "moderate." Latent variables, store atmosphere $(\mathrm{X})$ and customer satisfaction $(\mathrm{Z})$ that affect the variable of customer loyalty $(\mathrm{Y})$ in the structural model have an $\mathrm{R}^{2}$ value of 0.603 which indicates that the model is "moderate."

The appropriateness $\mathrm{Q}^{2}$ are:

$$
\begin{aligned}
\mathrm{Q}^{2} & =1-\left[\left(1-\mathrm{R}_{1}\right)\left(1-\mathrm{R}_{2}\right)\right] \\
& =1-[(1-0.559)(1-0.603)] \\
& =1-[(0.441)(0.397)]
\end{aligned}
$$




$$
\begin{aligned}
& =1-[(0.175) \\
& =\quad 0.825
\end{aligned}
$$

The $\mathrm{Q}^{2}$ result achieved is 0.825 , meaning that the $\mathrm{Q}^{2}>0$, the model has the predictive relevance.

The inner model, which is sometimes also the relationship between research structural model. This test is needed to determine the significance of the impact. The inner model serves to test hypotheses and also know the strength of the relationship between latent variables. The PLS output on the figure 2.

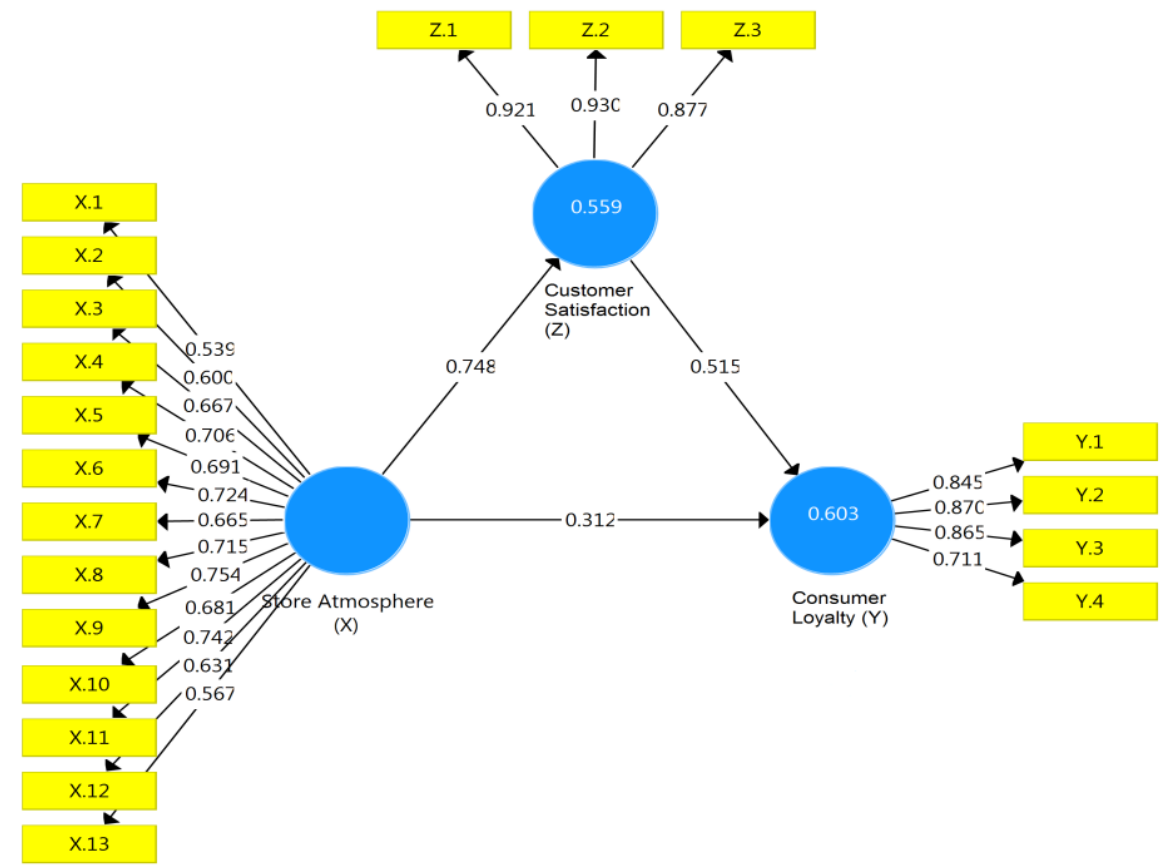

Fig. 2. The inner model or the structural model

\subsection{Hypothesis testing}

To answer hypothesis testing, see t-statistic in Table 7.

Tabel 7. Hypothesis testing

\begin{tabular}{lcccc}
\hline & $\begin{array}{c}\text { Original } \\
\text { Sample } \\
(\mathbf{O})\end{array}$ & $\begin{array}{c}\text { Sample } \\
\text { Mean } \\
(\mathbf{M})\end{array}$ & $\begin{array}{c}\text { Standard } \\
\text { Deviation } \\
(\text { STDEV })\end{array}$ & $\begin{array}{c}\text { T Statistics } \\
(\mid \mathbf{O S T D E V})\end{array}$ \\
\hline $\begin{array}{l}\text { Direct } \\
\text { Store Atmosphere (X) -> Consumer }\end{array}$ & 0.748 & 0.747 & 0.037 & 20.362 \\
$\begin{array}{l}\text { Satisfaction (Z) } \\
\begin{array}{l}\text { Store Atmosphere (X) -> Consumer Loyalty } \\
(Y)\end{array}\end{array}$ & 0.312 & 0.312 & 0.073 & 4.299 \\
$\begin{array}{l}\text { Consumer Satisfaction (Z) -> Consumer } \\
\begin{array}{l}\text { Loyalty (Y) } \\
\text { Indirect }\end{array}\end{array}$ & 0.515 & 0.514 & 0.071 & 7.210 \\
$\begin{array}{l}\text { Store Atmosphere (X) -> Consumer } \\
\text { Satisfaction (Z) -> Consumer Loyalty (Y) }\end{array}$ & 0.385 & 0.384 & 0.059 & 6.570 \\
\hline
\end{tabular}


Test results show that:

(i) The Effect of Store Atmosphere on Consumer Satisfaction: Store atmosphere has a significant effect on customer satisfaction, because the t-statistic value is 20.362 which means it is greater than 1.96. This means that "Store atmosphere affects the consumer satisfaction in beauty salon services" is proved significant.

The results store atmosphere has a positive significant effect to customer satisfaction. Positive effects that occur prove that the better the atmosphere of the store created, the more it will increase the feeling of satisfaction in the minds of consumers. This means that if the beauty salon services want to increase customer satisfaction, it is important to the store atmosphere of the beauty salon services in Surabaya. This is the same as the opinion of Miswanto and Angelia, who said that the pleasant atmosphere in the store would affect the level of consumer satisfaction [7].

(ii) The Effect of Store Atmosphere on Consumer Loyalty: The store atmosphere has a significant impact to consumer loyalty and t-statistic value is 4.299 which means it is greater than 1.96. This means that the second hypothesis in this study which reads "Store Atmosphere affects the consumer's loyalty in beauty salon services," is proved significant.

The results of hypothesis testing prove that the store atmosphere has a significant positive effect on consumer loyalty. The positive influence that occurs between the store atmosphere variable with consumer loyalty can be interpreted that the more fun the store atmosphere is created, the more it will increase consumer loyalty. This means that if the beauty salon services pay more attention to the atmosphere of the store created, it will increasingly trigger consumers to be loyal and choose the beauty salon services in Surabaya as a choice in the future as a form of consumer loyalty. Consumer loyalty is a strong commitment to buying back consistently selected products or services in the future, despite the influence of the situation and marketing efforts that have the potential to cause behavior change [11).

(iii) The Effect of Consumer Satisfaction on Consumer Loyalty: Consumer satisfaction has a significant influence on customer loyalty because of the t-statistic value of 7.210 which means greater than 1.96 . This means that the third hypothesis in this study which reads "Consumer satisfaction affects the consumer's loyalty in beauty salon services," is proved significant.

The results of testing the hypothesis described above prove that consumer satisfaction has a significant effect on customer satisfaction with a positive effect. The positive influence between customer satisfaction and customer loyalty can be interpreted as a direct effect, so it can be said that higher customer satisfaction will increasingly have an impact on increasing customer loyalty. Thus if the beauty salon services want to increase consumer loyalty, it is very important to pay attention to the level of satisfaction felt by consumers towards the beauty salon services.

The results of this study are in line with the findings of Furoida and Maftukhah, who found that customer satisfaction affects consumer loyalty [9]. Carranza and Diaz's research results, which also prove that consumer satisfaction has a significant effect on customer loyalty [5].

(iv) Effect Store Atmosphere on Consumer Loyalty through Consumer Satisfaction: Consumer satisfaction mediates the influence of store atmosphere on consumer loyalty because t-value of 6.570 and > 1.96. This means that the fourth hypothesis in this study which reads "Consumer satisfaction mediates the effect of store atmosphere on consumers loyalty in beauty salon services," is proved significant. 


\section{Conclusion}

Store atmosphere has a significant effect on customer satisfaction, which indicates that the better store atmosphere or store atmosphere that is presented by beauty salon services in Surabaya to consumers will increase consumer satisfaction, especially in better room lighting to be able to increase the attractiveness of the beauty salon, given the item get the highest rating on the store atmosphere variable.

Store atmosphere has a significant effect on consumer loyalty, which means that if the beauty salon services in Surabaya can implement a better store atmosphere, it will increasingly be able to increase consumer loyalty, especially in better room lighting in order to be able to increase the attractiveness of beauty salon, bearing in mind the item gets a rating the highest in the store atmosphere variable.

Increase the consumer satisfaction have impact to increase the consumer loyalty. In other words, satisfied consumers are in using the services the beauty salon services in Surabaya, the more it can influence consumers to be more loyal. This means that customer satisfaction is important, especially increasing overall satisfaction, given the item gets the highest rating on the store atmosphere variable. In other words, the more satisfied the customer is in using the services of the beauty salon services in Surabaya, the more influence the store atmosphere will have on the formation of consumer loyalty.

\section{References}

1. B. Berman, J.R. Evans, Retail Management: A Strategic Approach. Upper Saddle River. Prentice Hall Intl, Inc. (2012). https://pdfs.semanticscholar.org/4f83/3afde7642d5ee8c304535406f339a22eb6ec.pdf

2. M. Sezgin, S. Küçükköylü, Journal of Advanced Management Science, 2,3:186192(2014). http://www.joams.com/uploadfile/2014/0217/20140217020801895.pdf

3. C.H. Wang, S. Ha, Journal of Fashion Marketing and Management. 15,3:326344(2011). https://www.emeraldinsight.com/doi/abs/10.1108/13612021111151923R.

4. P. Kotler, K.L. Keller, Marketing Management, New York: Pearson Education, Inc. (2016) https://www.pearson.com/us/higher-education/product/Kotler-MarketingManagement-15th-Edition/9780133856460.html

5. Carranza, E. Diaz, Journal of Hospitality and Tourism Technology, 9,3:380396(2018). https://www.emeraldinsight.com/doi/abs/10.1108/JHTT-09-2017-0104

6. J.A.M. Garcia, L.M. Caro, Management Decision, 47,1:151-172(2009). https://www.emeraldinsight.com/doi/abs/10.1108/00251740910929768

7. Miswanto, Y.R. Angelia, Jurnal Manajemen Dan Kewirausahaan, 19,2:106111(2017). [in Bahasa Indonesia]. http://jurnalmanajemen.petra.ac.id/index.php/man/article/view/20393

8. D.C. Dabija, R. Babut, Procedia - Social and Behavioral Sciences, 109,109:906912(2014). https://papers.ssrn.com/sol3/papers.cfm?abstract_id=2580349

9. F. Furoida, I. Maftukhah, Management Analysis Journal 7,2:25-32(2018).

10. J.F. Jr. Hair, W.C. Black, B.J. Babin, R.E. Anderson. Multivariate Data Analysis: A Global Perspective, Upper Saddle River, NJ: Prentice Hall (2010). https://is.muni.cz/el/1423/podzim2017/PSY028/um/_Hair_Multivariate data analysis 7 th_revised.pdf

11. R.L. Oliver. Journal of Marketing, 63:33-44(1999) http://citeseerx.ist.psu.edu/viewdoc/download?doi=10.1.1.454.2827\&rep=rep1\&type= pdf 